\title{
Evaluasi Status Keberlanjutan Penggunaan Lahan di Das Ciliwung Bagian Hulu
}

\author{
Evaluation Of Landuse Sustanainability Status in Upper Ciliwung \\ Watershed
}

\section{Erwin Hermawan ${ }^{1}$, Santun R.P. S² ${ }^{\text {, Marimin }}{ }^{3}$, Suria Darma Tarigan ${ }^{4}$}

Diterima: 6 Februari 2019 Disetujui: 15 November 2019

\begin{abstract}
Abstrak: DAS Ciliwung bagian Hulu tergolong kedalam 15 DAS yang harus dipulihkan. Penelitian ini bertujuan untuk mengevaluasi kondisi eksisting status keberlanjutan penggunaan lahan berdasarkan aspek lingkungan, ekonomi dan sosial di Wilayah DAS Ciliwung Bagian Hulu. Teknik Multidimensional Scalling melalui pengembangan aplikasi RapWatershed digunakan untuk mengevaluasi Status Keberlanjutan penggunaan lahan di DAS Ciliwung bagian hulu. Hasil penelitian menunjukan secara umum identifikasi terhadap penggunaan lahan berkelanjutan pada tiap Sub DAS di kawasan DAS Ciliwung bagian Hulu tergolong ke dalam kategori Cukup berkelanjutan. Kondisi Sub DAS di kawasan DAS Ciliwung Hulu yang tergolong cukup baik pada kondisi cukup berkelanjutan secara Lingkungan, ekonomi dan Sosial yakni Sub DAS Ciliwung Hulu dan Sub DAS Cisarua. Sub DAS Cibalok dan Sub DAS Ciesek perlu diperhatikan khusus untuk status keberlanjutan pada dimensi lingkungan dan ekonomi.
\end{abstract}

Kata Kunci: keberlanjutan penggunaan lahan, multidimensional scalling, DAS Ciliwung bagian hulu

\begin{abstract}
The Upper Ciliwung watershed is classified into 15 watersheds that must be restored. This study aims to evaluate the existing conditions of the sustainability status of land use based on environmental, economic and social aspects in the Upper Ciliwung Watershed Region. The Multidimensional Scaling technique through the development of the Rap-Watershed application was used to evaluate the Status of Sustainability of land use in the upstream Ciliwung watershed. The results of the study show that in general the identification of sustainable land use in each subwatershed in the Upper Ciliwung watershed is categorized as moderately sustainable. The condition of the sub-watersheds in the Ciliwung Hulu watershed which is quite good in conditions that are sufficiently environmentally, economically and socially sustainable are the Upper Ciliwung watershed and the Cisarua watershed. The Cibalok sub-watershed and the Ciesek subwatershed need to be considered specifically for the status of sustainability in the environmental and economic dimensions.
\end{abstract}

Keywords: landuse sustainability, multidimensional scalling, upper Ciliwung Watershed

\footnotetext{
1 Program Studi Ilmu Pengelolaan Sumberdaya Alam dan Lingkungan, Sekolah Pascasarjana Institut Pertanian Bogor

1 Program Studi Teknik Informatika, Fakultas Teknik, Universitas Ibn Khaldun - Bogor

2,4 Departemen Ilmu Tanah dan Sumberdaya Lahan. Fakultas Pertanian. Institut Pertanian Bogor

3 Departemen Teknologi Industri Pertanian, Fakultas Teknologi Pertanian. Institut Pertanian Bogor
} 


\section{PENDAHULUAN}

Ekosistem bagian hulu DAS Ciliwung merupakan bagian yang penting karena mempunyai fungsi perlindungan terhadap seluruh bagian DAS. Selama hubungan timbal balik antar komponen dalam sistem DAS dalam keadaan seimbang maka sistem tersebut berada dalam keadaan stabil. jika terjadi gangguan pada sebagian komponen, maka kestabilan sistem menjadi terganggu (Baja et al. 2012). DAS Ciliwung bagian Hulu termasuk dalam 15 DAS prioritas yang harus dipulihkan (KLHK 2015). DAS yang dipulihkan daya dukungnya adalah DAS yang kondisi lahan serta kualitas, kuantitas dan kontinuitas air, sosial ekonomi, investasi bangunan air dan pemanfaatan ruang wilayah tidak berfungsi sebagaimana mestinya (Baja et al. 2012 ; KLHK 2015)

Tekanan pembangunan yang tinggi pada sub DAS Ciliwung Bagian Hulu menyebabkan DAS ini tergolong salah satu DAS yang mengalami degradasi (Dewi et al., 2009; Yustika et al. 2012). Kondisi ini dicirikan oleh pengelolaan lahan yang tidak sesuai dengan kemampuannya dan tidak disertai dengan usaha konservasi tanah dan air, serta perubahan pola penggunaan lahan bervegetasi (Yustika et al. 2012 ; Ali et al. 2016). Hasil penelitian Ruspendi et al (2012), menunjukan bahwa luas permukiman di DAS Ciliwung bagian hulu meningkat secara substansial dari tahun 2001 sampai 2010 sebesar $67.88 \%$. Pola perubahan tutupan lahan utama dari tahun 1990, 2001 dan 2010 adalah: (a) hutan kebun campuran - permukiman. (b) tegalan - kebun campuran - permukiman (c) sawahkebun campuran-permukiman (d) perkebunan - kebun campuran - permukiman (e) hutan/semak - semak - permukiman. Penurunan luas lahan bervegetasi dan peningkatan luas lahan terbangun tersebut telah meningkatkan debit puncak hidrograf pada stasiun katulampa dari $150 \mathrm{~m}^{3} / \mathrm{dt}$ menjadi $205 \mathrm{~m}^{3} / \mathrm{dt}$.

Dengan demikian, pengaturan penggunaan lahan melalui perencanaan penggunaan lahan berkelanjutan diperlukan sebagai upaya dalam pengelolaan DAS Ciliwung bagian hulu. Penggunaan lahan yang berkelanjutan (sustainable landuse) adalah penggunaan lahan yang dapat memenuhi kebutuhan saat ini dan pada saat yang sama dapat mengkonversi sumber daya alam untuk generasi mendatang (Cao et al., 2017). Dalam zonasi Penggunaan Lahan DAS, keberlanjutan penggunaan lahan baik kolektif maupun individual, daerah hilir sangat dipengaruhi oleh jenis pemanfaatan dan pengelolaan lahan pada daerah hulu. Dengan demikian, penggunaan lahan harus direncanakan bagi dan oleh masyarakat secara keseluruhan karena konservasi tanah, air dan sumberdaya lahan lainnya sering diluar kemampuan penggunaan lahan secara individu (Baja et al., 2012 ; Basuki 2016). Lebih lanjut, Sitorus (2017) menyebutkan perencanaan penggunaan lahan berkelanjutan adalah suatu perencanaan penggunaan lahan yang bertujuan untuk keberlanjutan yang meyeimbangkan kebutuhan sosial. ekonomi dan lingkungan. Penelitian ini bertujuan untuk mengevaluasi kondisi eksisting status keberlanjutan penggunaan lahan berdasarkan aspek lingkungan, ekonomi dan sosial pada tiap Sub DAS di Wilayah DAS Ciliwung Bagian Hulu.

\section{METODE PENELITIAN}

\section{Lokasi Penelitian}

Penelitian dilakukan di DAS Ciliwung Bagian Hulu yang secara geografis terletak pada 6 $6^{\circ} 37^{\prime} 30^{\prime \prime}$ - 6 $6^{\circ} 46^{\prime} 10^{\prime \prime}$ LS dan 106 $49^{\prime} 36^{\prime \prime}$ - 1070'15" BT dengan luasan sekitar \pm 14 617,62 Ha. Wilayah Sub DAS Ciliwung Bagian Hulu terbagi kedalam 7 Sub DAS sebagaimana ditunjukan pada Gambar 1. 


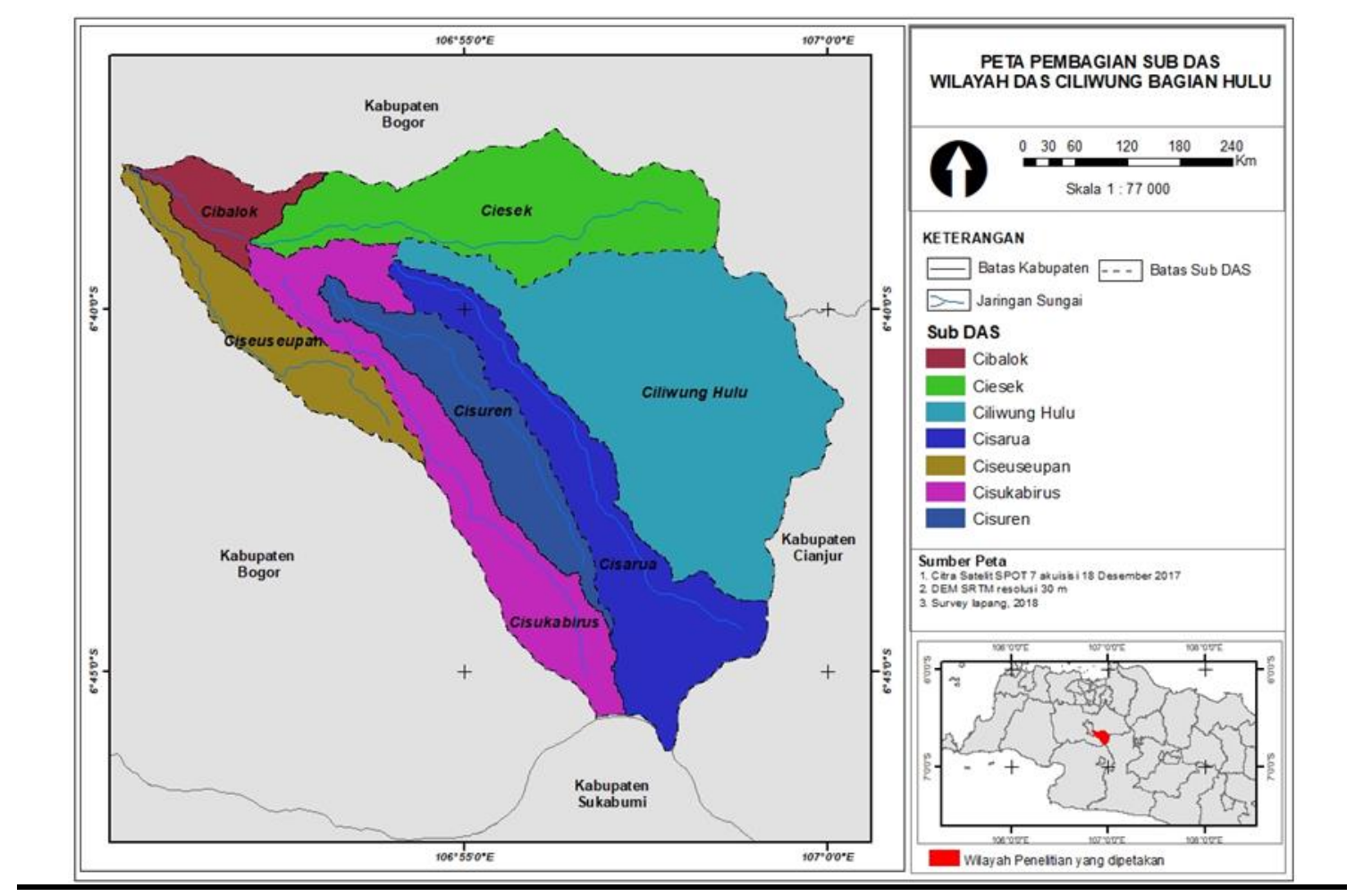

Gambar 1. Peta Pembagian Sub DAS pada Lokasi Penelitian

\section{Data dan Metode}

Data yang digunakan dalam penelitian ini adalah data primer dan data sekunder. Data primer diperoleh dan dikumpulkan langsung melalui observasi lapang seperti ground chek penggunaan lahan, sedangkan untuk beberpa parameter ekonomi dan sosial dilakukan wawancara mendalam (In-depth Interview) dengan pakar dan responden yang menjadi informan kunci di lapangan. Data Sekunder diperoleh dari beberapa instansi terkait meliputi : Citra satelit SPOT 6/7 yang mengcover wilayah penelitian, Data Iklim tahun 2007 - 2017, Peta Rencana Tata Ruang Wilayah Kabupaten Bogor, Peta Batas administratif tingkat kecamatan di Kabupaten Bogor, Peta DAS dan Sub DAS Ciliwung Bagian Hulu,Peta Fungsi kawasan hutan, Peta Jenis Tanah serta Peta Lahan kritis.

Metode analisis yang digunakan dalam penelitian ini yakni menerapkan teknik multidimensional Scalling (MDS) untuk mengevaluasi status keberlanjutan penggunaan lahan di DAS Ciliwung Bagian Hulu yang dikembangkan dalam sebuah aplikasi RapWatershed. Aplikasi ini merupakan hasisk modifikasi dari program Rapfish (Rapid Appraisal for Fisheries) yang dikembangkan oleh University of British Colombia-Kanada untuk menilai kebelanjutan suatu sistem (Fauzi dan Anna, 2005).

Teknik MDS memetakan dua titik atau objek yang sama dalam satu titik yang saling berdekatan. Sebaliknya, obyek atau titik yang berbeda digambarkan dengan titik-titik yang berjauhan. Nilai skor pada setiap atribut akan membentuk suatu matriks $X\left(\begin{array}{lll}n & x & p\end{array}\right)$, di mana $n$ adalah jumlah wilayah beserta titik-titik acuannya dan $p$ adalah jumlah atribut yang digunakan. Nilai skor tersebut kemudian distandardisasi untuk setiap nilai skor atribut. sehingga setiap atribut memiliki bobot seragam dan perbedaan antar skala pengukuran dapat dihilangkan. Pitcher et al., 2001 dan Kavanagh et al., 2004 merumuskan metode standardisasi sebagai berikut: 


$$
X_{i k} s d=\frac{X_{i k}-X_{k}}{S_{k}}
$$

Dimana :

$$
\begin{aligned}
& \begin{aligned}
X_{i k} s d: & \text { nilai skor standar wilayah (termasuk titik acuannya) } \mathrm{ke}-\mathrm{i}=1.2 \ldots . \mathrm{n} \text {. pada } \\
& \text { setiap atribut ke-k }=1.2 \ldots \mathrm{p}
\end{aligned} \\
& X_{i k} \quad \text { : nilai skor awal wilayah (termasuk titik-titik acuannya) ke }-\mathrm{i}=1.2 \ldots \mathrm{n} \text {. } \\
& \text { pada setiap atribut ke-k }=1.2 \ldots \text { p } \\
& X_{k} \quad \text { : nilai tengah skor pada setiap atribut ke-k }=1.2 \ldots . \mathrm{p} \\
& S_{k} \quad: \quad \text { simpangan baku skor pada setiap atribut ke-k }=1.2 \ldots . \mathrm{p}
\end{aligned}
$$

Kavanagh et al., (2004) menyebutkan bahwa teknik MDS dalam Rapfish dilakukan dengan menghitung jarak terdekat dari Euclidian distance berdasarkan persamaan (3) :

$$
d_{12}=\sqrt{\left(x_{1}-x_{2}\right)^{2}+\left(y_{1}-y_{2}\right)^{2}}
$$

Jarak Euclidean antara dua titik tersebut $\left(\mathrm{d}_{12}\right)$ kemudian diproyeksikan ke dalam jarak Euclidean dua dimensi $\left(\mathrm{D}_{12}\right)$ dan e merupakan nilai error. dirumuskan dalam persamaan (2).

$$
d_{12}=a+b D_{12}+e
$$

Pada Rapfish, proses regresi tersebut menggunakan algoritma ALSCAL dengan prinsip membuat pengulangan (iteration) proses regresi tersebut sehingga mampu menghasilkan nilai error terkecil. Menurut Kavanagh dan Pitcher (2004) algoritma ALSCAL pada Rapfish memaksa agar nilai intercept pada persamaan tersebut sama dengan nol $(\mathrm{a}=0)$ sehingga persamaan (4) menjadi persamaan (5) berikut:

$$
d_{12}=b D_{12}+e
$$

Proses pengulangan terhenti. jika nilai stress lebih kecil dari 0.25 . Nilai stress diperoleh berdasarkan persamaan (6).

$$
\text { Stress }=\sqrt{\frac{1}{m} \sum_{k=1}^{m}\left[\frac{\sum_{i} \sum_{j}\left(D_{i j k}-d_{i j k}\right)^{2}}{\sum_{i} \sum_{j} d_{i j k}^{2}}\right]}
$$

Pengaruh error akan muncul dalam analisis MDS yang disebabkan oleh berbagai hal, seperti : (1) kesalahan dalam pembuatan skor karena kesalahan pemahaman terhadap atribut atau kondisi lokasi penelitian yang belum sempurna, (2) variasi nilai akibat perbedaan opini atau penilaian oleh peneliti (3) kesalahan pemasukan data atau ada data yang hilang dan (4) tingginya nilai stress. Nilai stress $<25 \%$ merupakan nilai stress yang dapat diterima. Evaluasi pengaruh error pada proses pendugaan nilai ordinasi keberlanjutan dapat dilakukan dengan menggunakan analisis Monte Carlo. Kavanagh dan Pitcher (2004) menyebutkan . Goodness of fit dalam MDS dicerminkan dari besaran nilai S (Stress) dan $\mathrm{R}^{2}$. Model yang baik ditunjukkan dengan nilai $\mathrm{S}$ yang lebih kecil dari 0.25 dan $\mathrm{R}^{2}$ yang 
mendekati 1. Skala indeks keberlanjutan sistem yang dikaji mempunyai selang 0 - 100 persen.

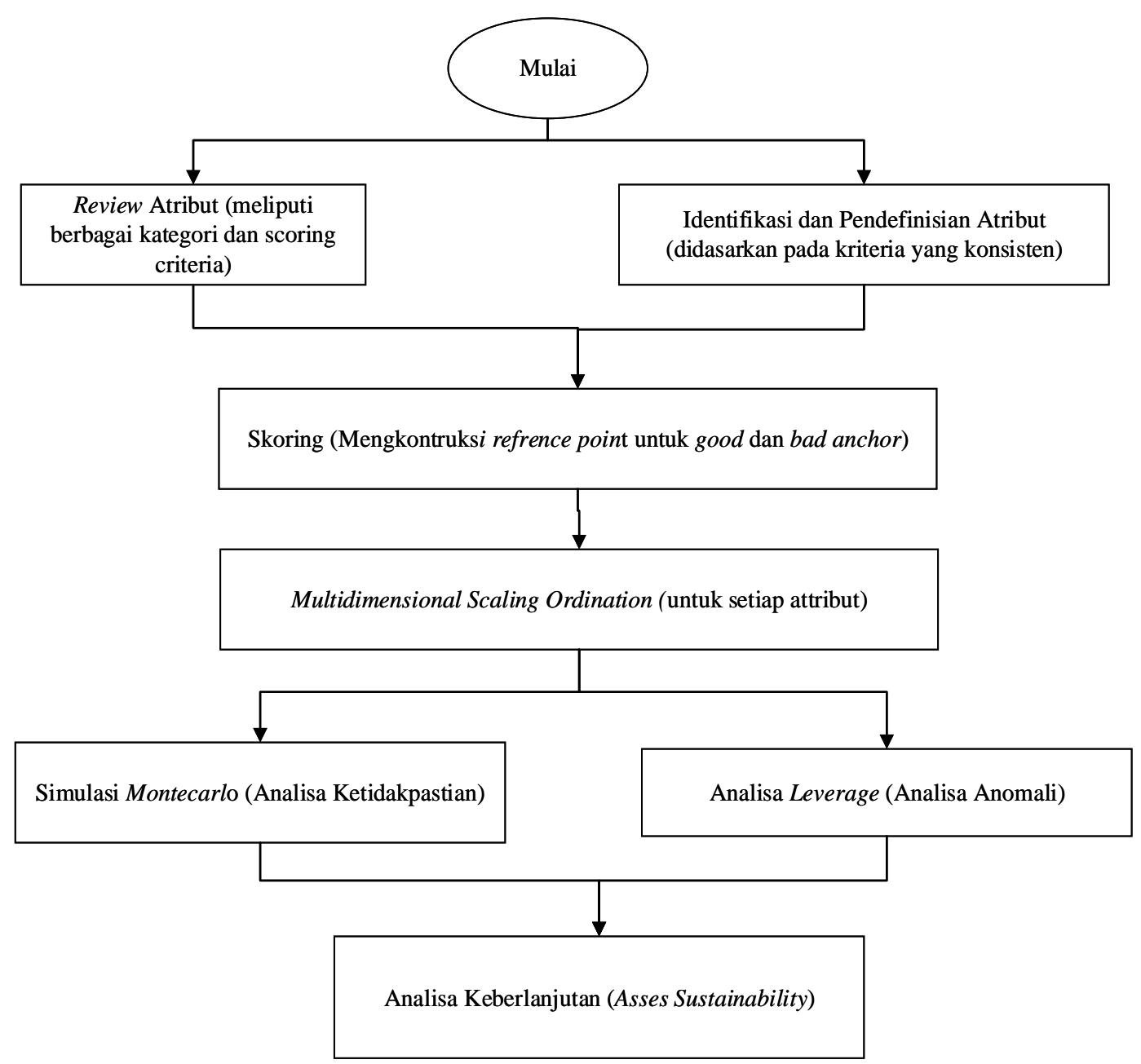

(Dimodifikasi/diadopsi dari Fauzi dan Ana,2005).

\section{Gambar 2. Tahapan analisis Multidimensional Scalling}

Tahapan analisis Multidimensional scalling sebagaimana tersaji pada Gambar 2, dilakukan melalui beberapa tahapan yaitu : (1) Penentuan atribut yang mencakup 4 Dimensi (ekologi, ekonomi dan sosial) (2) Penilaian setiap atribut dalam skala ordinal (skoring) berdasarkan kriteria keberlanjutan setiap dimensi (3) Analisis ordinasi untuk menentukan ordinasi dan nilai stress (4) Menilai indeks dan status keberlanjutan pengelolaan DAS Ciliwung Bagian Hulu yang dikaji baik secara multidimensi maupun pada setiap dimensi (5) Analisis kepekaan (Leverage Analysis) untuk menentukan peubah yang sensitif mempengaruhi keberlanjutan; dan (6) Analisis Monte Carlo untuk memperhitungkan aspek ketidakpastian.

\section{HASIL DAN PEMBAHASAN}

\section{Analisa Keberlanjutan pada Dimensi Lingkungan}

Hasil analisa keberlanjutan penggunaan lahan untuk dimensi lingkungan menunjukan, status keberlanjutan pada tiap Sub DAS memiliki nilai kurang dari 50 yang 
menandakan posisi status keberlanjutan cukup sampai kurang berlanjut, sebagaimana tersaji pada Gambar 3. Hal ini sejalan dengan penelitian Suwarno et al. (2010) yang menyebutkan bahwa nilai status keberlanjutan DAS Ciliwung bagian hulu untuk Dimensi lingkungan sebesar 36,82 yang mengindikasikan kondisi DAS Ciliwung Hulu berdasarkanan dimensi Lingkungan termasuk dalam status kurang berkelanjutan. Kondisi dengan status kurang berkelanjutan terdapat pada 3 Sub DAS, yakni (1) Sub DAS Ciesek, (2) Sub DAS Cisuren dan (3) Sub DAS Cibalok dengan nilai status keberlanjutan berturut turut 15.94, 20.55 dan 22.20. Di sisi lain, kondisi dengan status keberlanjutan cukup, terdapat pada 4 Sub DAS yakni (1) Sub DAS Ciseuseupan, (2) Sub DAS Cisukabirus, (3) Sub DAS Ciliwung Hulu dan (4) Sub DAS Cisarua dengan nilai status keberlanjutan berturut - turut 30.76, 38.57, 37.39 dan 43.78. Berdasarkan hasil analisa tersebut, kondisi Sub DAS yang perlu perhatian khusus untuk dilakukan pemulihan untuk dimensi lingkungan yaitu pada kondisi Sub DAS dengan status keberlajutan cukup berkelanjutan yakni sub DAS Ciesek, Cibalok dan Cisuren.

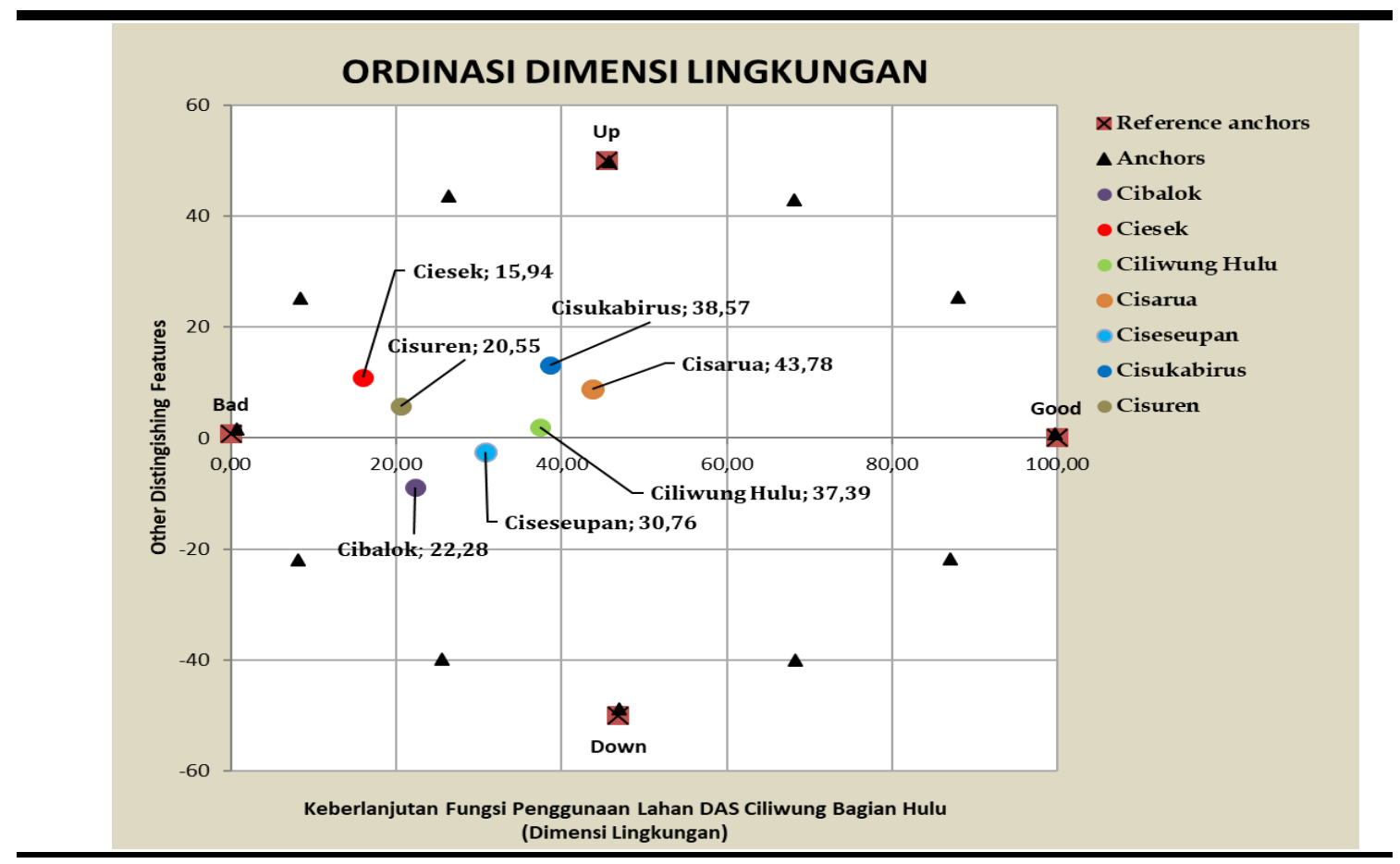

Gambar 3. Status keberlanjutan Penggunaan lahan pada Dimensi Lingkungan

Penilaian status keberlanjutan pada dimensi lingkungan dilakukan berdasarkan atribut - atribut pengungkit yang telah dianalisa. Berdasarkan hasil analisis leverage sebagaimana terlihat pada Gambar 4, dari 6 atribut yang dianalisa terdapat 4 atribut yang sensitif mempengaruhi besarnya nilai indeks keberlanjutan dimensi lingkungan, yaitu (1) Aliran permukaan dengan nilai 4.86, (2) Koefisien Regim Sungai (KRS) dengan nilai 6.84 dan (3) Koefisien Aliran Tahunan (KAT) dengan nilai 3.86 dan (4) Lahan Kritis dengan nilai 3.86. Atribute tersebut perlu mendapatkan perhatian khusus dengan dilakukan pengelolaan lebih baik sehingga dapat meningkatkan nilai status keberlanjutan yang lebih baik di masa mendatang. Hasil penelitian ini sejalan dengan penelitian yang dilakukan Fitria et al (2017) yang menyebutkan bahwa aliran permukaan di DAS Ciliwung bagian hulu cukup tinggi. Salah satu teknik untuk mengendalikannya yakni dengan penerapan teknik konservasi, penanaman strip dapat menghambat aliran permukaan hingga $74.52 \%$. 


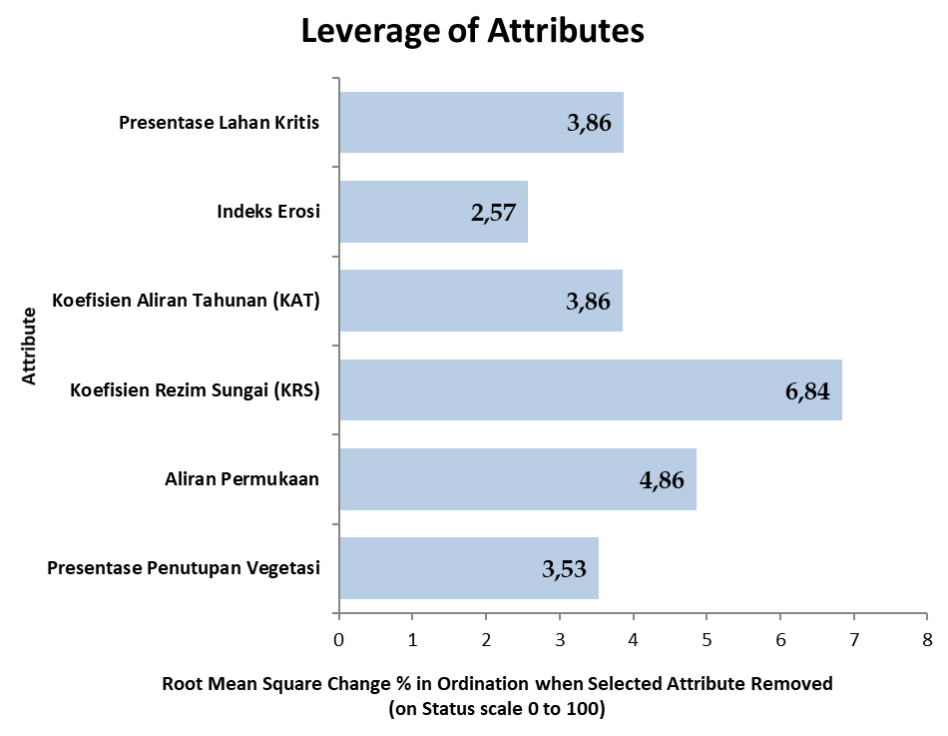

\section{Gambar 4. Faktor Sensitif yang mempengaruhi Keberlanjutan Penggunaan lahan pada Dimensi Lingkungan}

\section{Analisa Keberlanjutan pada Dimensi Ekonomi}

Hasil analisa keberlanjutan penggunaan lahan untuk dimensi ekonomi menunjukan, status keberlanjutan pada tiap Sub DAS secara dominan memiliki nilai kurang 50 yang menandakan posisi status keberlanjutan cukup sampai kurang berlanjut. Kondisi status keberlanjutan kurang berkelanjutan terdapat pada 2 Sub DAS, yakni (1) Sub DAS Ciesek dan (2) Sub DAS Cibalok dengan nilai status keberlanjutan berturut turut 15.16 dan 25.52. Di sisi lain, kondisi dengan status keberlanjutan cukup, terdapat pada 4 Sub DAS yakni (1) Sub DAS Cisukabirus (2) Sub DAS Cisuren, (3) Sub DAS Ciseuseupan dan (4) Sub DAS Ciliwung Hulu dengan nilai status keberlanjutan berturut - turut 36.58, 37.93, 40.61 dan 48.02. Sub DAS Cisarua memiliki nilai status keberlanjutan paling tinggi pada dimensi eknomi dibandingkan sub DAS lainnya dengan nilai 52.59. Hal ini menunjukan, penggunaan lahan di Sub DAS Cisarua bisa dimanfaatkan dengan baik secara ekonomi oleh masyarakat yang tinggal di kawasan Sub DAS Cisarua. Kondisi Sub DAS yang perlu perhatian khusus untuk dilakukan pemulihan untuk dimensi ekonomi yaitu pada kondisi Sub DAS dengan status keberlajutan cukup berkelanjutan yakni sub DAS Ciesek dan Sub DAS Cibalok. Gambar 5, menjelaskan ordinasi yang memetakan posisi keberlajutan pada tiap Sub DAS untuk dimensi ekonomi.

Penilaian status keberlanjutan pada dimensi ekonomi dilakukan berdasarkan atribut - atribut pengungkit yang telah dianalisa. Berdasarkan hasil analisis leverage sebagaimana terlihat pada Gambar 6, dari 6 atribut yang dianalisa terdapat 4 atribut yang sensitif mempengaruhi besarnya nilai indeks keberlanjutan dimensi ekonomi, yaitu (1) Luas kepemilikan lahan pertanian dengan nilai 3.58, (2) penyerapan tenaga kerja pada sektor pertanian dengan nilai 3.45 dan (3) Tingkat pendapatan yang dihasilkan dari sektor dengan nilai 3.86 dan (4) Jumlah tenaga kerja terampil pada sektor pertanian nilai 3.30. Attribute tersebut perlu mendapatkan perhatian khusus dengan dilakukan pengelolaan lebih baik sehingga dapat meningkatkan nilai status keberlanjutan terkait pemanfaatan penggunaan lahan pada aspek ekonomi yang lebih baik di masa mendatang. 


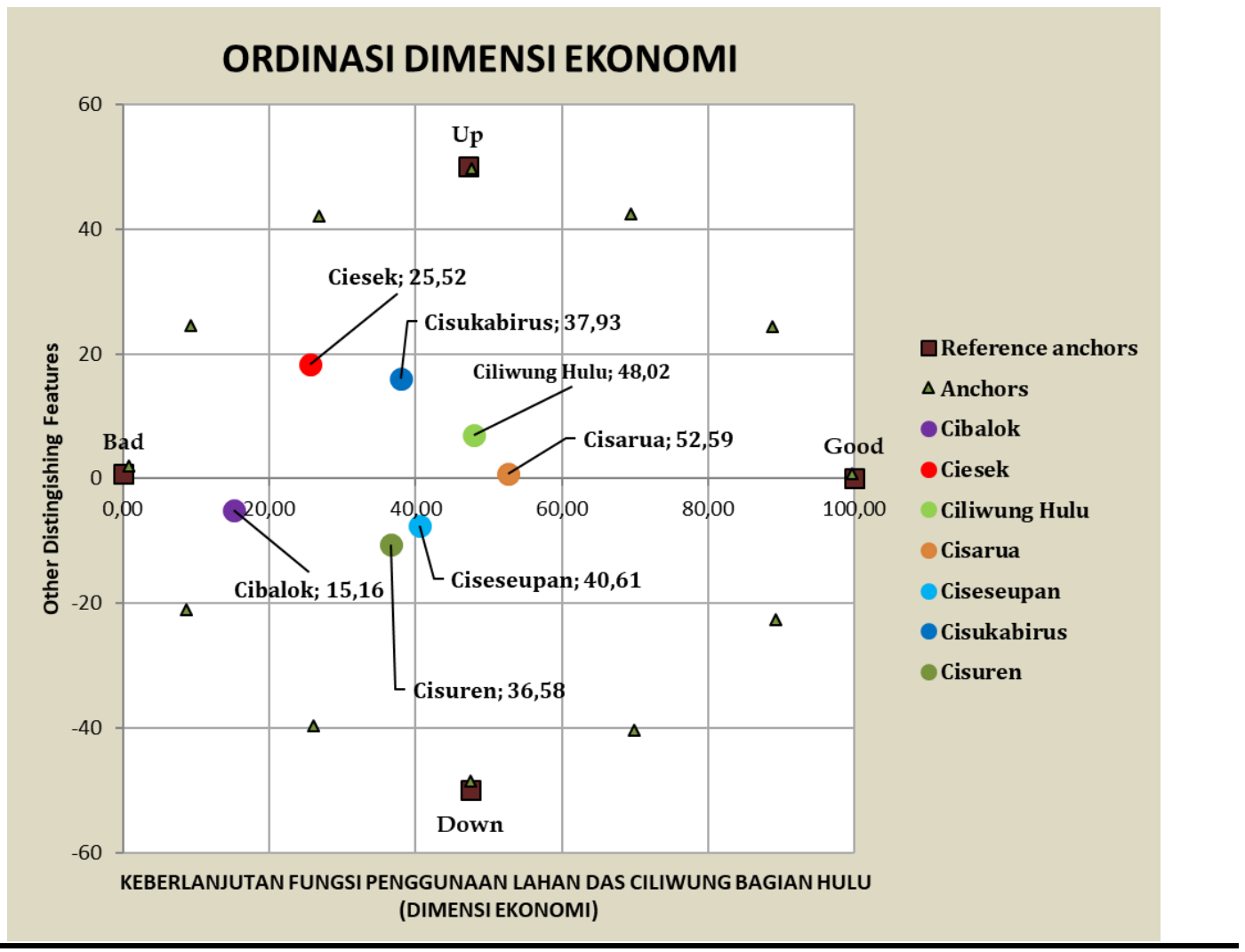

Gambar 5. Status keberlanjutan Penggunaan lahan pada Dimensi Ekonomi

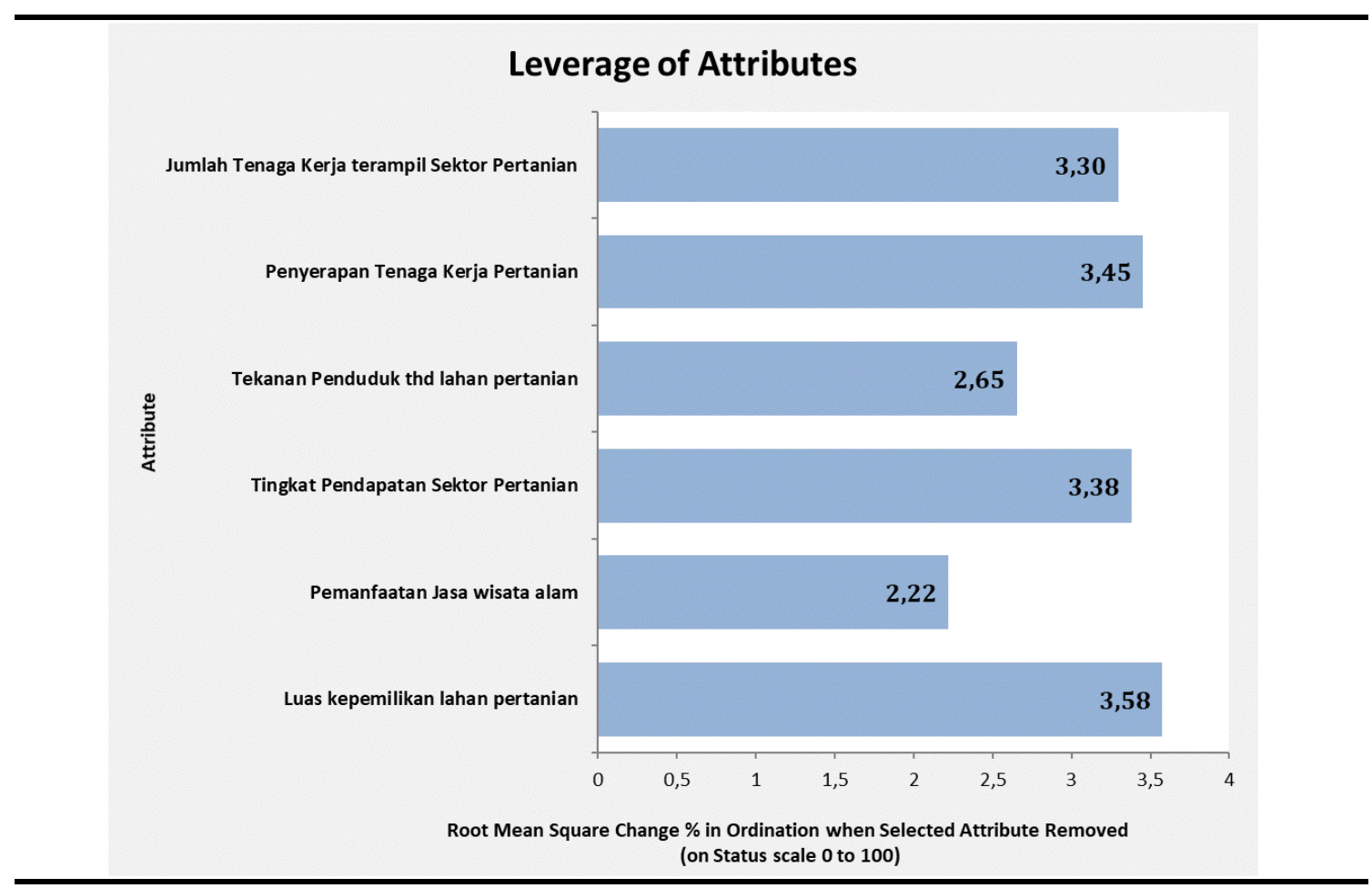

Gambar 6. Faktor Sensitif yang mempengaruhi Keberlanjutan Penggunaan lahan pada Dimensi Ekonomi 


\section{Analisa Keberlanjutan pada Dimensi Sosial}

Ordinasi yang memetakan posisi keberlajutan pada tiap Sub DAS untuk dimensi sosial dijelaskan pada Gambar 7. Hasil analisa keberlanjutan penggunaan lahan pada dimensi sosial menunjukan, status keberlanjutan pada tiap Sub DAS secara umum berada pada nilai cukup keberlanjutan. Kondisi dengan nilai status cukup keberlanjutan terdapat pada 6 Sub DAS, yakni (1) Sub DAS Ciesek, (2) Sub DAS Cisuren, (3) Sub DAS Ciseuseupan, (4) Sub DAS Cisukabirus dan (5) Sub DAS Ciliwung Hulu dan (6) Sub DAS Cisarua dengan nilai status keberlanjutan berturut turut 42.13, 40,23, 47,36, 42,48, 32.88 dan 40.48. Di sisi lain, kondisi dengan status keberlanjutan cukup, terdapat pada $4 \mathrm{Sub}$ DAS yakni dengan nilai status keberlanjutan berturut - turut 30.76, 38.57, 37.39 dan 43.78. Sub DAS Cibalok memiliki nilai status keberlanjutan paling tinggi pada dimensi sosial dibandingkan sub DAS lainnya dengan nilai 54.87. Hal ini menunjukan, pengelolaan pemanfaatan penggunaan lahan dari aspek di Sub DAS Cibalok terkelola dan termanfaatkan dengan baik. Di sisi lain kondisi pada 6 sub DAS lainnya diperlukan perhatian khusus untuk dilakukan pengelolaan dengan lebih baik.

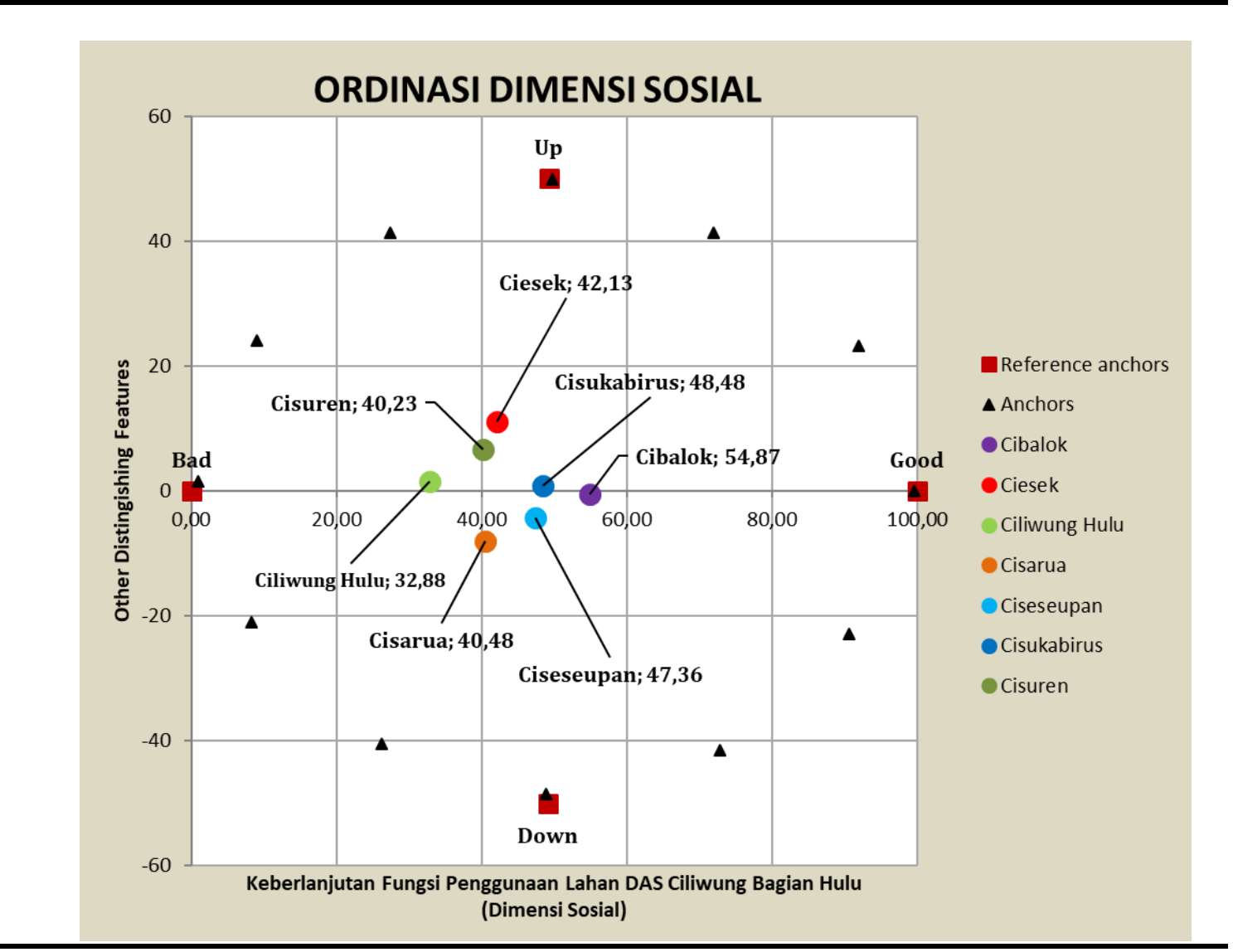

Gambar 7. Status keberlanjutan Penggunaan lahan pada Dimensi Sosial

Berdasarkan hasil analisis leverage untuk dimensi sosial sebagaimana terlihat pada Gambar 7, dari 6 atribut yang dianalisa terdapat 3 atribut yang sensitif mempengaruhi besarnya nilai indeks keberlanjutan dimensi sosial, yaitu (1) Tingkat inkonsistensi penggunaan lahan eksisting dengan Pola Ruang pada Rencana Tata RuangWilayah (RTRW) Kabupaten Bogor dengan nilai 4.37, (2) Tingkat pendidikan masyarakat yang tinggal di kawasan DAS Ciliwung bagia Hulu dengan nilai 3.70 dan (3) konflik pemanfaatan sumberdaya alam di kawasan DAS Ciliwung bagian Hulu dengan nilai 2.97. 
Hasil ini memperkuat pernyataan Rusdiana et al. (2003) bahwa tingginya tingkat inkonsistensi antara RTRW dengan penggunaan lahan eksisting di DAS Ciliwung bagian Hulu disebabkan oleh kurang sinergisitasnya antara stakeholders terkait dalam upaya pengeloaan DAS. Pengelolaan terhadap atrribut yang sensitif terhadap keberlanjutan dimensi sosial perlu dilakukan sehingga dapat meningkatkan nilai status keberlanjutan terkait pemanfaatan penggunaan lahan pada aspek sosial yang lebih baik di masa mendatang.

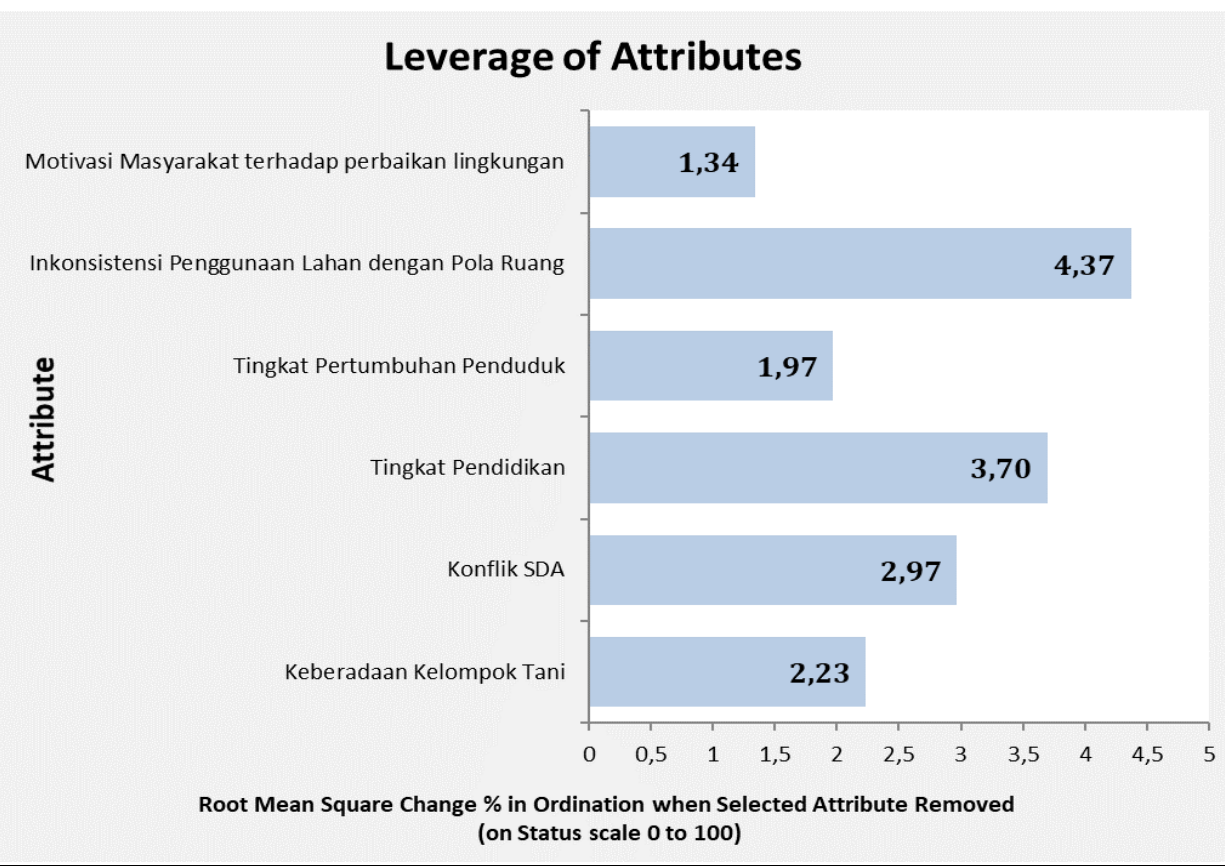

Gambar 7. Faktor Sensitif yang mempengaruhi Keberlanjutan Penggunaan lahan pada Dimensi Sosial

\section{Multidimensional ScallingAnalisis dan Validasi Keberlanjutan}

Hasil identifikasi terhadap status keberlanjutan yang telah dilakukan pada tiap dimensi, dapat digabungkan dan diperbandingkan secara keseluruhan dalam bentuk Multidimensional Scalling Analysis (MDS). Tabel 1, menunjukan Nilai Status keberlanjutan dimensi Lingkungan, Ekonomi dan Sosial pada tiap Sub DAS di Wilayah DAS Ciliwung bagian Hulu. Rerata nilai status keberlanjutan pada tiap dimensi di DAS Ciwung bagian hulu berada pada nilai kurang dari 50 yang mengindikasikan status keberlanjutan kurang berkelanjutan. Namun demikian, berdasarkan hasil perbandingan Sub DAS Ciliwung Hulu dan Sub DAS Cisarua memiliki nilai yang lebih tinggi pada dimensi Lingkungan dan ekonomi, sedangkan Sub DAS Cibalok dan Sub DAS Ciesek perlu diperhatikan khusus untuk peningkatan status keberlanjutan pada dimensi lingkungan dan ekonomi.

Tabel 1. Nilai Status keberlanjutan dimensi Lingkungan, Ekonomi dan Sosial pada tiap Sub DAS.

\begin{tabular}{llrrc}
\hline \multirow{2}{*}{ No } & Sub DAS & \multicolumn{3}{c}{ Status Keberlanjutan } \\
\cline { 3 - 5 } & & Lingkungan & Ekonomi & Sosial \\
\hline 1 & Cibalok & 22,28 & 15,16 & 54,87 \\
2 & Ciesek & 15,94 & 25,52 & 42,13 \\
3 & Ciliwung Hulu & 37,39 & 48,02 & 32,88 \\
4 & Cisarua & 43,78 & 52,59 & 40,48 \\
\hline
\end{tabular}




\begin{tabular}{llrrc}
\hline \multirow{2}{*}{ No } & Sub DAS & \multicolumn{3}{c}{ Status Keberlanjutan } \\
\cline { 3 - 4 } 5 & & Lingkungan & Ekonomi & Sosial \\
6 & Ciseseupan & 30,76 & 40,61 & 47,36 \\
6 & Cisukabirus & 38,57 & 37,93 & 48,48 \\
7 & Cisuren & 20,55 & 36,58 & 40,23 \\
DAS Ciliwung Bagian Hulu & 29,90 & 36,63 & 43,78 \\
\hline
\end{tabular}

Gambar 8, menunjukan diagram layang keterkaitan posisi status keberlanjutan antar Sub DAS pada tiap Dimensi. Sub DAS Cisarua terlihat paling tinggi status keberlanjutan pada dimensi lingkungan dan ekonomi dibandingkan sub DAS yang lainnya, namun kurang berkelanjutan untuk dimensi sosial. Kondisi Sub DAS yang perlu diperhatikan khusus untuk dilakukan pemulihan yakni Sub DAS Ciesek yang terdapat pada posisi kurang berkelanjutan pada dimensi Lingkungan dan ekonomi di bandingkan Sub DAS lainnya.

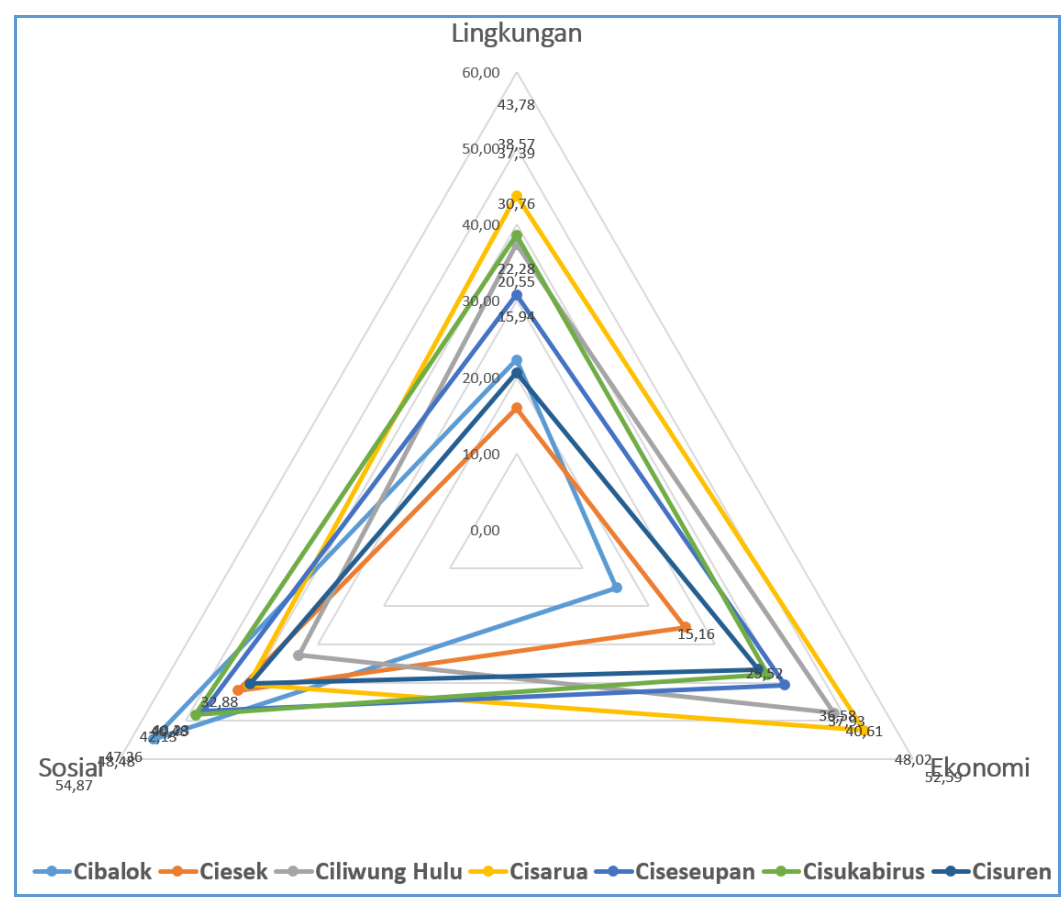

Gambar 8. Diagram Layang Analisis Indeks dan Status Pemanfaatan Penggunaan lahan berkelanjutan

Validasi terhadap hasil analisa MDS dapat dianalisa berdasarkan nilai parameter statististik yang dikeluarkan oleh model Rap - Landuse for Watershed, yakni berdasarkan pada nilai "S-Strees dan Koefisien determinasi $\left(\mathrm{R}^{2}\right)$. Hasil keluaran model sebagaimana ditunjukan pada Tabel 2, menunjukan nilai S-Stress $<0.25$, artinya hasil luaran model sudah cukup signifikan. Begitupun untuk nilai koefisien determinasi yang dihasilkan pada taraf selang kepercayaan $95 \%$ didapatkan nilai koefisien yang signifikan mendekati 1 untuk tiap dimensi.

Pengujian hasil lainnya yakni dengan membadingkan antara hasil analisa MDS dengan hasil analisis Monte Carlo, sebagaimana dapat terlihat pada Tabel 3. Hasil yang didapatkan menunjukan perbedaan hasil antara nilai MDS dan monte carlo pada selang kepercayaan $95 \%$ tidak banyak mengalami perbedaan dengan selisih kurang dari 1. 
Kecilnya perbedaan nilai indeks keberlanjutan antara hasil analisis kedua metode tersebut mengindikasikan bahwa (1) kesalahan dalam pembuatan skor setiap atribut relatif kecil, (2) Perbedaan opini relative kecil dalam pemberian (3) Proses iterasi model relative stabil. Perbedaan yang relative kecil yakni kurang dari 1 antara hasil simulasi MDS dan montecarlo menunjukkan bahwa sistem yang dikaji memiliki tingkat kepercayaan yang tinggi.

Tabel 2. Parameter Statistik (Goodness of fit) dari Analisis Indeks dan Status Keberlanjutan

\begin{tabular}{lrrr}
\hline Parameter Statistik & Lingkungan & \multicolumn{1}{c}{ Ekonomi } & \multicolumn{1}{c}{ Sosial } \\
\hline S Stress & 0,174 & 0,223 & 0,214 \\
$\mathrm{R}^{2}$ & 0,935 & 0,922 & 0,914 \\
\hline
\end{tabular}

Tabel 3. Hasil Analisis Monte Carlo Multidimensi dengan Selang Kepercayaan $95 \%$

\begin{tabular}{|c|c|c|c|c|c|c|c|c|c|c|}
\hline \multirow[t]{2}{*}{ No } & \multirow[t]{2}{*}{ Sub DAS } & \multicolumn{3}{|c|}{$\begin{array}{l}\text { Dimensi } \\
\text { Lingkungan }\end{array}$} & \multicolumn{3}{|c|}{ Dimensi Ekonomi } & \multicolumn{3}{|c|}{ Dimensi Sosial } \\
\hline & & $a$ & $\mathrm{~b}$ & $C$ & $\mathrm{a}$ & $\mathrm{b}$ & c & $a$ & $\mathrm{a}$ & c \\
\hline 1 & Cibalok & 22,28 & 22,71 & 0,43 & 15,16 & 16,01 & 0,85 & 54,87 & 55,36 & 0,49 \\
\hline 2 & Ciesek & 15,94 & 16,23 & 0,29 & 25,52 & 26,13 & 0,61 & 42,13 & 42,44 & 0,31 \\
\hline 3 & $\begin{array}{l}\text { Ciliwung } \\
\text { Hulu }\end{array}$ & 37,39 & 37,50 & 0,11 & 48,02 & 48,46 & 0,44 & 32,88 & 33,28 & 0,40 \\
\hline 4 & Cisarua & 43,78 & 44,45 & 0,67 & J2 & 52,97 & 38 & 40,48 & 4 & 0,27 \\
\hline 5 & Ciseseupan & 30,76 & 31,37 & 0,60 & 40,61 & 41,25 & 0,64 & 47,36 & 47,39 & 0,03 \\
\hline 6 & Cisukabirus & 38,57 & 39,19 & 0,62 & 37,93 & 38,58 & 0,64 & 48,48 & 48,55 & 0,07 \\
\hline 7 & Cisuren & 20,55 & 20,61 & 0,06 & 36,58 & 40,81 & 4,24 & 40,23 & 40,84 & 0,60 \\
\hline
\end{tabular}

Keterangan : $\mathrm{a}=$ Hasil MDS, $\mathrm{b}=$ Hasil monte carlo, $\mathrm{c}=$ Selisih antara Hasil MDS dan Monte Carlo

\section{KESIMPULAN}

Secara umum identifikasi terhadap penggunaan lahan berkelanjutan pada tiap Sub DAS di kawasan DAS Ciliwung bagian Hulu tergolong ke dalam kategori kurang berkelanjutan dengan nilai status keberlanjutan di bawah 50 untuk tiap dimensi. Namun demikian, berdasarkan hasil perbandingan Sub DAS Ciliwung Hulu dan Sub DAS Cisarua memiliki nilai yang relatif lebih tinggi pada dimensi Lingkungan dan ekonomi tapi perlu diperhatikan untuk peningkatan status keberlanjutan pada dimensi sosial, sedangkan Sub DAS Cibalok dan Sub DAS Ciesek sudah cukup baik pada dimensi sosial namun perlu diperhatikan khusus untuk peningkatan status keberlanjutan pada dimensi lingkungan dan ekonomi

\section{PERNYATAAN RESMI}

Ucapan terima kasih disampaikan kepada Kementerian Riset, Teknologi dan Pendidikan Tinggi Direktorat Jenderal Penguatan Riset dan Pengembangan, Direktorat Riset dan Pengabdian Masyarakat atas bantuan hibah penelitian disertasi doktor pendanaan 2018. BPDASHL Citarum Ciliwung dan PSDA Citarum Cisadane atas dukungan data sekunder yang diberikan dalam penelitian ini.

\section{DAFTAR PUSTAKA}

Ali M, Hadi S, Sulistyantara B. 2016. Study on Land Cover Change of Ciliwung Downstream Watershed with Spatial Dynamic Approach. Procedia-Social and Behavioral Sciences. 227: 52-59.

Baja IS, Phil M. 2012. Perencanaan Penggunaan Lahan dalam Pengembangan Wilayah. Jakarta [ID]. Penerbit Andi. Basuki TM. 2016. Indikator dan Parameter Kriteria Lahan Untuk Monitoring Dan Evaluasi Kinerja Sub-DAS. Jurnal Penelitian Hutan dan Konservasi Alam. 11(3):281-297. 
Cao K .2017. 1.17 Spatial Optimization for Sustainable Land Use Planning. Comprehensive Geographic Information Systems, 244.

Dewi IK, Surjono HS, Kholil K, Arifin HS. 2009. Dynamic Model for Settlement Area Management in The Upper Stream of Ciliwung Watershed, Bogor District-Indonesia. Proceeding of International Symposium of Green City: The Future Challenge, 10-11 August 2009/IPB International Convention Center, Bogor. IPB-IFLA-FPALI-IALI-Sentul City

Fauzi A, Anna S. 2002. Evaluasi status keberlanjutan pembangunan perikanan: aplikasi pendekatan Rapfish (studi kasus perairan pesisir DKI Jakarta). Journal of Coastal and Marine Resources. 4 (3): 14-21.

Fauzi A, Anna S. 2005. Pemodelan Sumberdaya Perikanan dan Kelautan untuk Analisis Kebijakan. Jakarta (ID): PT Gramedia Pustaka Utama.

Fitri, R., Tarigan, S. D., Sitorus, S. R., \& Rachman, L. M. (2018). Perencanaan Penggunaan Lahan Untuk Pengembangan Agroforestri di DAS Ciliwung Hulu Provinsi Jawa Barat. TATALOKA, 20(2), 148-159.

Kavanagh, P. and Pitcher, T.J. (2004) Implementing Microsoft Excel Software for Rapfish: A Technique for the Rapid Appraisal of Fisheries Status. Fisheries Centre Research Reports 12(2): 75pp.

[KLHK] Kementerian Lingkungan Hidup dan Kehutanan. 2015. Peraturan Direktur Jenderal Pengendalian Daerah Aliran Sungai dan Hutan Lindung, Nomor : P 10 /PDASHL-SET/2015 Tentang Rencana Strategis Direktorat Jenderal Pengendalian Daerah Aliran Sungai Dan Hutan Lindung Tahun 20152019. Jakarta (ID) ; KLHK.

Pitcher TJ, Preikshot D. 2001. RAPFISH: a rapid appraisal technique to evaluate the sustainability status of fisheries. Fisheries Research, 49(3): 255-270.

Rusdiana O, Sudaryanto, Ichwandi I, Arifjaya NM, Hendrayanto, Soekmadi R. . 2003. Hubungan Kerjasama Institusi Dalam Pengelolaan Daerah Aliran Sungai Kasus DAS Ciliwung. Bogor[ID]. Fakultas Kehutanan - Institut Pertanian Bogor.

Ruspendi D, Hadi S, Rusdiana O. 2016. Kajian Perubahan Penutupan Lahan pada DAS Ciliwung Bagian Hulu dengan Pendekatan Spasial Dinamik. Jurnal Lanskap Indonesia. 5(2) : 1-5.

Sitorus SRP. 2017. Perencanaan Penggunaan Lahan. Bogor [ID]: IPB Press.

Suwarno J, Kartodiharjo H, Pramudya B, Rachman S. 2011. Pengembangan Kebijakan Pengelolaan Berkelanjutan DAS Ciliwung Bagian Hulu Kabupaten Bogor. Jurnal Analisis Kebijakan Kehutanan. $8(2): 115-131$.

Yustika RD, Tarigan SD, Hidayat Y, Sudadi U. 2012. Simulation of Land Management in Hulu Ciliwung use SWAT Model. Informatika Pertanian. 21 (2): 71 - 79. 